PESQUISAS - RESEARCHES

\title{
Filosofia, religião e oriente: o caso Nietzsche
}

\author{
Derley Menezes Alves \\ Professor no Instituto Federal de Sergipe - Doutorando em Ciências das Religiões pela Universidade Federal da Paraíba \\ derley@gmail.com
}

Recebido em 29/04/2016. Aprovado em 11/11/2016.

Como citar este artigo: Alves, Derley Menezes. "Filosofia, religião e oriente: o caso Nietzsche". Intelligere, Revista de História Intelectual, São Paulo, v. 3, n 1 [4], p. 130-143. 2017. ISSN 2447-9020. Disponível em

$<$ http://revistas.usp.br/revistaintelligere $>$. Acesso em dd/mm/aaaa.

Resumo: O objetivo do presente trabalho é apresentar o problema do budismo no pensamento de Nietzsche. Para fazer isso é preciso em primeiro lugar refletir acerca do estatuto da filosofia da religião dentro do campo das ciências das religiões a partir da descoberta das religiões do extremo oriente feita pelos orientalistas. Em seguida é preciso analisar a recepção e impacto das pesquisas sobre religiões orientais no pensamento de um dos grandes mestres de Nietzsche, Schopenhauer. Por fim falaremos das possibilidades interpretativas no que diz respeito ao budismo na obra deste autor.

Palavras-chave: Nietzsche, budismo, ciências das religiões, relações oriente e ocidente.

Philosophy, religion and the East: the case of Nietzsche.

\begin{abstract}
This work intends to discuss the relation between east and west considering how researches about the east, especially those of the nineteenth century, were read and interpreted by philosophers. We focus our analysis in Nietzsche and the Buddhism as representatives of the West and the East. This is a first step into a more detailed reading of such themes.
\end{abstract}

Keywords: Nietzsche, Buddhism, Sciences of Religions, relations between the West and the East. 
O objetivo deste trabalho é apresentar uma reflexão acerca das interações entre ocidente e oriente. Do lado do ocidente tomamos como referência para tal análise a filosofia de Nietzsche e do lado do oriente tomamos como referência o budismo, tradição acerca da qual esse filósofo manifestou interesse ao longo de toda sua vida. Dividimos nossa análise em três momentos distintos, a saber, considerações acerca da filosofia da religião enquanto componente do campo das ciências das religiões; um panorama histórico breve acerca de interações entre filosofia e religião na tradição filosófica; o contato de Schopenhauer com o budismo e por fim o contato de Nietzsche com essa mesma tradição.

A pergunta acerca da relação entre a filosofia de Nietzsche e o budismo é filosófica? É possível para a filosofia lidar com tradições orientais, dadas as diferenças entre estas e a tradição filosófica? Seria tal investigação exclusiva das ciências das religiões, a despeito de haver um filósofo envolvido na formulação do problema? Tais perguntas nos levam a refletir acerca das relações entre filosofia - como filosofia da religião - e o campo das ciências das religiões.

De um lado temos no Brasil uma coletânea de artigos organizada por Frank Usarski intitulada O Espectro Disciplinar das Ciências das Religiões, ${ }^{1}$ na qual não consta filosofia da religião enquanto um componente do espectro disciplinar para a área das ciências das religiões, nem mesmo na primeira parte da obra, dedicada às subdisciplinas clássicas da ciência da religião. Nem mesmo a fenomenologia da religião foi incluída nesta obra, disciplina que, embora oriunda da tradição filosófica apresenta quanto aos estudos das religiões desenvolvimentos próprios e distintos do modo filosófico de fazer fenomenologia.

Temos ainda o livro As Ciências das Religiões, ${ }^{2}$ de Giovanni Filoramo e Carlo Prandi que, embora não lidem com a filosofia da religião diretamente apresentam um capítulo dedicado à fenomenologia da religião e por fim o único livro que podemos apontar até o presente momento que apresenta um capítulo acerca da filosofia da religião. Trata-se da obra Introdução à Ciência da Religião ${ }^{3}$ de Klaus Hock. Esse silêncio nos causa estranheza pois entendemos que filosofia da religião tem legitimidade para figurar como subárea das ciências das religiões. Passemos agora a algumas considerações acerca da história da filosofia em suas relações com a religião com o objetivo de deixar clara a constância do diálogo entre filosofia e religião ao longo da história daquela. Com isso queremos superar possíveis estranhamentos ao se falar de diálogos entre filosofia e religiões orientais.

Em primeiro lugar, a filosofia nasce como contraponto à tradição religiosa grega, oferecendo soluções diversas para os mesmos problemas tratados na tradição mitológica deste povo, a saber, problemas relativos a origem do cosmo. Algumas destas soluções são marcadamente naturalistas, como por exemplo as oferecidas pelos pensadores de Mileto. Tales, considerado pela tradição o primeiro filósofo, nos diz que todas as coisas são originadas a partir de transformações do elemento água. Outros pensadores como Anaxágoras vão mencionar a existência de uma mente ou nous como princípio ordenador.

Ainda na tradição grega temos pensadores como Platão, que defende claramente ter sido o mundo criado por um Demiurgo ao mesmo tempo que tece críticas ao modo popular de se conceber os deuses, tido por ele como prejudicial para a felicidade na cidade ideal. Tampouco vemos Aristóteles defender alguma forma de ateísmo, ao contrário, o conhecimento supremo é chamado por este autor de teologia ou ontologia. Mesmo o epicurismo, apesar de ser uma filosofia materialista, não é necessariamente ateísta, não nega que há deuses, apenas afirma que tais deuses nada têm a ver conosco e vivem vidas bem-aventuradas alheias ao mundo humano.

${ }^{1}$ Frank Usarski (org.) O Espectro Disciplinar da Ciência da Religião (São Paulo: Paulinas, 2007).

${ }^{2}$ Giovanni Filoramo e Carlo Prandi. As Ciências das Religiões, trad., ed. José Maria de Almeida (São Paulo: Paulus, 1999).

${ }^{3}$ Klaus Hock, Introdução à Ciência da Religião, trad., ed. Monika Ottermann. (São Paulo: Edições Loyola, 2010). 
Em segundo lugar temos, com a ascensão do cristianismo, a aliança entre filosofia e teologia, que atravessará todo período medieval, de modo que religião era o solo dado a partir do qual se refletia. Renascimento e modernidade nos apresentam a evolução de uma postura mais crítica em relação à religião - neste caso o cristianismo - apesar de poucos autores abertamente ateus. Temos na modernidade Descartes considerando a prova da existência e bondade de Deus como peça fundamental para a fundamentação do conhecimento, bem como David Hume criticando o cristianismo de modo mais elaborado, a partir daquilo que a nova ciência oferecia em termos de conhecimento e métodos de investigação. Lembremos aqui os Diálogos sobre a Religião Natural, obra dedicada a criticar o argumento do desígnio. ${ }^{4}$ Este livro, apesar de todo cuidado do autor, ao fazer o crítico do argumento do desígnio "perder" o debate na forma do texto, apesar da força de seus argumentos, só veio a público após a morte de Hume, pois o mesmo receava possíveis perseguições.

De acordo com Klaus Hock, apesar de todo este diálogo com tradições religiosas ao longo de sua história, é com Kant que filosofia da religião entra na lista de disciplinas filosóficas. Diz-nos este autor que o texto kantiano que inaugura essa disciplina é $A$ Religião nos Limites da Simples Razão. O específico da abordagem kantiana é que

Kant atribuiu à Filosofia da Religião a tarefa de criar, com a ajuda de uma religião fundamentada na razão, o fundamento da moral na qual se baseia toda a sociedade. No entanto, quanto mais se mostraram as consequências destrutivas da razão, tanto mais questionável tornou-se a absolutização da razão, como ela foi realizada no iluminismo. ${ }^{5}$

Na obra de Hegel também temos uma filosofia da religião. Hegel parte de Deus como fundamento da religião, o que já compromete seu pensamento com a teologia. Dentro de seu esquema interpretativo temos três grandes momentos da religião, a saber, religião da natureza, religião da arte e religião revelada. No primeiro caso os objetos imediatos são sacralizados, no segundo caso as obras de arte e no terceiro e mais elevado o espírito entra em contato consigo mesmo, é quando temos a ideia do Deus encarnado. Importante notar que o cristianismo é fundamental à obra de Hegel porque possibilita sua filosofia da história, na qual o autor nos apresenta o caminho da consciência rumo ao Espírito Absoluto. Trata-se do mesmo percurso, seja na história da Razão, seja na da Religião. Em resumo, a filosofia da religião se Hegel se vincula fortemente à teologia cristã, como de modo geral é o caso na história da filosofia, em que pese contatos ocasionais com sistemas religiosos diferentes do cristianismo. A partir da consolidação do cristianismo temos ou uma filosofia cristã ou uma filosofia que se posiciona contra ou de modo crítico ao cristianismo. De qualquer modo a referência principal sempre será a tradição cristã.

A partir de fins do XVIII e inícios do XIX adentramos o romantismo, movimento marcado entre outras coisas por uma desconfiança com a razão e uma valorização dos sentimentos e do que não é razão no homem. Neste contexto temos a ascensão de estudos sobre o oriente, movidos pelas descobertas do colonialismo e por uma busca romântica acerca das origens da religião cristã e da religião primordial da humanidade. As pesquisas neste campo tornam possível, pela primeira vez que filósofos lidem com a religião fora do âmbito da cultura grega clássica (uma religião morta) e do campo do cristianismo e das tradições monoteístas do judaísmo e do islamismo tendo como base estudos e textos traduzidos a partir das línguas orientais. Não se fala mais de uma única religião, mas de religiões, defenda-se uma unidade original das mesmas ou não. Além disso, temos a teoria da evolução, que fornece uma explicação completamente natural para a

\footnotetext{
${ }^{4}$ Trata-se de um argumento que pretende provar a existência de Deus considerando que há na natureza sinais evidentes de uma inteligência que deliberadamente fez as coisas do modo como são. Uma analogia comum nesse caso é comparar o mundo a um objeto fabricado por humanos encontrado ao acaso e que nos leva a pensar na inteligência que projetou tal artefato.

${ }^{5}$ Klaus Hock, Introdução à Ciência da Religião, 199.
} 
origem do ser humano, tornando pela primeira vez o ateísmo capaz de oferecer uma resposta possível para a questão da origem do ser humano sem depender de nenhuma crença religiosa. Esses dois eventos, cada um a seu modo acabam enfraquecendo o poder do cristianismo de fornecer as únicas respostas verdadeiras para as questões humanas e naturais.

Embora existam vários pesquisadores do oriente ao longo de fins do século XVIII e todo o XIX, gostaríamos de centrar nossa reflexão em dois filósofos que receberam tais pesquisas e se apropriaram delas cada um a seu modo, a saber, Schopenhauer e Nietzsche. Nosso objetivo aqui é apresentar um caminho para análise da relação entre este último e o budismo, mas para isso é preciso mencionar o caso de Schopenhauer. As questões que entendemos relevantes nesse caso são: quais as fontes lidas por esses pensadores e em que medida tais fontes exerceram sobre eles alguma influência.

Quanto a Schopenhauer percebemos duas questões no que diz respeito ao pensamento indiano, a saber, o primeiro contato deste autor com esta tradição, que se deu a partir principalmente daquilo que chamamos hoje de hinduísmo e o posterior contato deste com o budismo. Vinculada a essas questões temos a pergunta acerca da possível influência tanto do hinduísmo quanto do budismo no desenvolvimento da filosofia desse autor, ou seja, de que modo e em que medida Schopenhauer apropria-se do saber acerca da Índia disponível em seu tempo.

A primeira referência ao oriente na obra de Schopenhauer se mostra como uma pergunta a partir do curso de inverno (1810-1811) de psicologia ministrado por Gottlob Enst Schulze Mas os bindus? É a nota disponível seguindo a pesquisa de mestrado feita por Fábio Luiz de Almeida Mesquita. ${ }^{6}$ No verão do ano seguinte ele frequenta um curso de etnologia ministrado por Arnold Heeren. Este curso no deixou algumas anotações de aula e o conhecimento da existência dos Asiatic Researches, textos que serão lidos alguns anos depois (1815-16) bem como as primeiras referências de Schopenhauer acerca da religião indiana, especificamente dos Vedas. Ressaltemos que se tratam de referências coletadas, não de uma leitura e interpretação realizada por este autor.

O interesse de Schopenhauer cresce a ponto de ele pegar emprestado na biblioteca de Weimar os dois volumes das Asiatisches Magaz̧in e a tradução de Anquetil-Duperron dos Upanishades chamada de Oupnek'hat. Com essa obra chegamos em uma fonte que comprovadamente influenciou Schopenhauer na elaboração de sua filosofia. Podemos citar a utilização da figura do véu de Maya ou véu da ilusão como uma das influências mais fortes resultantes da leitura deste livro. Além dela temos também a expressão tat tvam asi, tu és isto, que em sua obra aprece como o reconhecimento que conduz a compaixão para com os seres, pois percebe-se que todos são o mesmo em essência, no caso de Schopenhauer, vontade. Podemos citar ainda a figura da trimurti, a trindade divina do hinduísmo, composta pelos deuses Brahma, Vishnu e Shiva, que em sua obra vai representar a discórdia da Vontade consigo mesma, posto que ela cria, mantém e destrói, respectivamente como cada um dos deuses é compreendido.

Passemos agora ao problema do budismo na obra de Schopenhauer. Primeiro é preciso mencionar a evolução da compreensão quanto a figura do Buda, em seguida investigar o modo como este autor se apropria criativamente de conceitos budistas em sua filosofia como as quatro nobres verdades, samsara e nirvana. Disto podemos concluir que a leitura de Schopenhauer é seletiva, posto que ele busca no oriente o que entende semelhante a sua filosofia.

No que diz respeito aos primeiros contatos de Schopenhauer com o budismo seguimos os dados apresentados por Deyve Redyson. ${ }^{7}$ Segundo esse pesquisador percebemos uma evolução na compreensão de Schopenhauer acerca do Buda, inicialmente localizado ainda dentro das tradições

\footnotetext{
${ }^{6}$ Fábio Luiz de Almeida Mesquita, "Schopenhauer e o Oriente” (Dissertação de mestrado, Universidade de São Paulo, 2007).

${ }^{7}$ Deyve Redysson, Schopenhauer e o Budismo: a impermanência, a insatisfatoriedade e a insubstancialidade (João Pessoa: Ideia/Editora Universitária, 2012)
} 
da Índia: "Nós podemos fixar o tempo de Buda ou a nona grande encarnação de Vishnu". Em seguida, após a leitura do artigo On the chronology of the Hindus Schopenhauer verificou que a palavra Fo seria a grafia chinesa para Buda. Na terceira nota, após entender que Shankara é um comentador do vedanta e citar Patanjali, Schopenhauer acredita que o pensamento de Gautama é uma escola filosófica além dos Vedas. ${ }^{8} \mathrm{~A}$ quarta nota, por fim menciona as diferenças entre as concepções de transmigração do vedanta e do budismo. O artigo On the religion and Manners of the people of Ceylon apresenta a Schopenhauer as várias escolas budistas, o que o faz perceber a necessidade de conhecer a doutrina do Buda em mais detalhe para que possa avaliar toda essa diversidade. Infelizmente ainda não havia material suficiente em sua época para tal empreitada.

Quanto a temas budistas que ecoam na obra schopenhaueriana cabe a pergunta: o impacto destes foi semelhante ao do Oupnek'bat? Schopenhauer foi também influenciado por conceitos budistas na elaboração de sua filosofia ou tal contato se deu a posteriori? Sabemos que ele menciona as quatro nobres verdades e os conceitos de samsara e nirvana. Qual o sentido de tais conceitos em sua obra? Considerando que a maioria das referências ao budismo se encontram no segundo volume d'o Mundo como Vontade e como Representação e nos dois volumes dos Parerga e Paralipomena, entendemos que se buscarmos uma possível influência de conceitos budistas na elaboração da filosofia de Schopenhauer teremos uma resposta negativa. ${ }^{9}$ As leituras mais próximas acerca do hinduísmo parecem ter sido mais importantes quanto a este ponto. Isso não quer dizer que este autor não tenha se interessado pelo budismo. As obras citadas acima apresentam muitas reflexões que não deixam dúvidas quanto ao conhecimento de Schopenhauer das pesquisas mais recentes acerca do assunto. Nesse sentido, é possível estabelecer comparações onde o próprio autor enxergou semelhanças e nesse processo entender como sua compreensão do budismo foi evoluindo moldada por suas leituras. Dado o caráter do presente texto, tais análises não cabem aqui. Passemos ao nosso tema principal, a saber, Nietzsche e sua relação com o budismo.

Temos neste cenário posturas diversas acerca do conhecimento que Nietzsche teria ou não acerca do oriente e do budismo. De um lado há os que defendem o Nietzsche profundo conhecedor do oriente, que teria aprendido sânscrito em Leipzig e que por conta de tais conhecimentos teria sido profundamente influenciado pelo budismo no desenvolvimento de sua filosofia. Como exemplo cito aproximações feitas entre temas nietzschianos e temas budistas: eterno retorno e samsara, Zaratustra e bodhisatva, transvaloração dos valores e nibbana. ${ }^{10}$ Uma segunda leitura entende que não há grande influência de tradições asiáticas em Nietzsche. Isto se evidenciaria pela raridade de referências ao longo da obra a ideias orientais e pelo fato de que quando tais referências ocorrem de modo geral são exemplos e não o foco central da reflexão. ${ }^{11}$

Uma vez que não temos trabalhos sobre a relação entre Nietzsche e o budismo no Brasil que refaçam este trajeto até o cânone páli (pelo que apuramos até o presente momento as pesquisas sobre o tema geralmente lidam coma relação entre Nietzsche e a tradição mahayana, que ao que tudo indica ou não foi lida por ele ou o foi muito pouco), e uma vez que a grande maioria do material com o qual Nietzsche teve contato tem os textos dessa tradição como referência, é preciso, para entender a relação efetiva deste autor com o budismo, que se considere, principalmente, essa tradição. Entendemos que é fundamental para qualquer pesquisa envolvendo budismo a delimitação clara de que tradição budista está sendo levada em consideração, uma vez que são vários e diversos os budismos, de modo que tal delimitação ajuda a trilhar caminhos e tem

\footnotetext{
8 Deyve Redysson, Schopenhauer e o Budismo: a impermanência, a insatisfatoriedade e a insubstancialidade, 144.

9 Tanto Redyson quanto o monge budista Nanajivako Bhikkhu estabelecem diálogos e comparações bastante frutíferos acerca do tema. Preferimos não entrar neste ponto para não prolongar o texto e porque nosso objetivo aqui é investigar acerca de primeiros contatos e possíveis influências na formulação dos projetos filosóficos. No caso de Schopenhauer isto é mais evidente pela via do hinduísmo, as referências ao budismo sendo posteriores.

${ }^{10}$ Tese defendida por Guy Welborn no livro The Buddhist Nirvana and It's Westerners Interpreters, conforme explicada no artigo de Benjamin A. Elman, "Nietzsche and Buddhism", Journal of the History of Ideas, [Vol.] 44, 4 (1983): 671-686.

${ }_{11} \mathrm{O}$ artigo de Mervyn Sprung analisado adiante apresenta uma variação dessa ideia.
} 
implicações no tipo de resultado a se alcançar. E, uma vez delimitada uma tradição budista com a qual Nietzsche teve um contato maior é preciso investigar principalmente o que ele teria lido acerca do assunto, posto que não havia tradução de todo cânone páli para línguas ocidentais com a qual ele pudesse ter tido contato.

Ao mesmo tempo que temos em Nietzsche um crítico das religiões em geral, como pode ser comprovado por livros como Humano, Demasiado Humano e Além do Bem e do Mal, não sendo o budismo exceção, temos na obra deste filósofo diversas passagens elogiosas ou que no mínimo assumem uma característica problemática do budismo ou do pensamento indiano de modo que este não poderia ser analisado do mesmo modo que o cristianismo, como por exemplo o final do capítulo acerca da natureza religiosa no Humano, Demasiado Humano, no qual lemos:

[...] não considerei os santos hindus, que se acham num nível intermediário entre o santo cristão e o filósofo grego, e portanto não representam um tipo puro: o conhecimento, a ciência - na medida em que existia - , a elevação acima dos demais homens pela disciplina e educação lógica do pensamentos, eram exigidos como sinal de santidade entre os budistas, enquanto os mesmos atributos, no mundo cristão, são rejeitados e denegridos como sinal de impiedade. ${ }^{12}$

Em Aurora temos no aforismo 96 um elogio do fenômeno histórico representado pelo budismo. Segundo Nietzsche, o Buddha teria dado um passo decisivo ao criar uma "religião da autorredenção", livre da submissão a uma casta ou igreja. A Gaia Ciência já no prólogo nos apresenta uma importante passagem na qual se fala da retirada para o Nada oriental - denominado Nirvana. Apesar de identificar Nada e Nirvana, há a sugestão de que tal mergulho pode nos tornar questionadores mais perspicazes e profundos.

Por vezes, temos passagens menos elogiosas acerca do budismo na obra de Nietzsche, budismo e cristianismo se equivalendo como religiões niilistas que propõem um tipo de fuga da realidade em direção ao nada (seja ele entendido como vida eterna, seja como nibbana). Este tipo de dualidade não é incomum na obra deste filósofo, especialmente se considerarmos seu método aforismático de fazer filosofia. Portanto, não é de pouca monta tentar entender a postura geral de Nietzsche no que diz respeito ao budismo.

Já no parágrafo 20 do Anticristo temos uma comparação entre budismo e cristianismo. Nessa comparação o budismo aparece como superior ao cristianismo.

Com minha condenação do cristianismo não quero ser injusto com uma religião aparentada, que pelo número de adeptos até o supera: o budismo. As duas são próximas por serem religiões niilistas - religiões de décadence - , as duas se diferenciam de modo bastante notável. ${ }^{13}$

Que diferenças Nietzsche aponta entre estas religiões aparentadas? O budismo é mais realista, vem de uma longa tradição reflexiva e por isso lida com os problemas de modo mais

\footnotetext{
${ }^{12}$ Friedrich Nietzsche, Humano, Demasiado Humano: um livro para espiritos livres, trad., ed. Paulo César de Souza (São Paulo: Companhia das letras, 2000).

${ }^{13}$ Friedrich Nietzsche, O Anticristo e Ditirambos a Dionísio, trad., ed. Paulo César de Souza (São Paulo: Companhia das letras, 2007).
} 
objetivo, trata-se de uma religião que já aboliu o conceito de deus e que além disso apresenta uma teoria do conhecimento fenomenalista o que indica seu caráter positivista.

Ainda neste passo Nietzsche aponta fatores fisiológicos importantes para o desenvolvimento do budismo. Um seria "uma enorme excitabilidade, que se exprime como suscetibilidade à dor", uma capacidade de sentir de modo mais intenso todo tipo de dor, ainda que diminuta, que seria expressa segundo entendemos, já no enunciado da primeira nobre verdade: dukkha, sofrimento ou insatisfação. O segundo seria uma hiperespiritualização, "uma demasiada permanência entre conceitos e procedimentos lógicos, na qual o instinto pessoal se prejudicou em favor da coisa 'impessoal"'. Nietzsche apela para a experiência partilhada entre ele e seus leitores igualmente "objetivos" neste ponto, o que sugere se tratar aqui de uma dedicação exacerbada a atividades racionais e este tipo de dedicação submete instintos pessoais a uma razão impessoal. Disso resulta depressão que é combatida pelo Buddha com medidas higiênicas, quais sejam, vida ao ar livre, as andanças e moderação alimentar. Do ponto de vista psicológico há no budismo o cultivo deliberado de ideias que produzam tranquilidade e evita-se o sentimento de vingança e o ressentimento. Nesse último aspecto parece haver um retorno ao egoísmo perdido na objetividade supracitada, na medida em que se busca o que é salutar para si mesmo e o fim do próprio sofrimento é o centro da prática.

Além disso o budismo tem a vantagem de ser um movimento pacífico oriundo das classes elevadas e que tem como objetivos "jovialidade, o sossego, a ausência de desejos" e tais objetivos são alcançados. Importante notar que a noção de nobreza é modificada pelo Buddha para significar não algo resultante das condições de nascimento da pessoa, mas sim o resultado de um modo de vida enobrecedor, o que estaria em tese aberto para pessoas das várias castas. Quanto aos objetivos citados, a ligação dos mesmos com a origem nobre do budismo parece derivar do fato de que nobres já levam de saída uma vida saturada de desejos e de todo tipo de agitação, inclusive agitações perigosas como tramas políticas e guerra.

O cristianismo tem como centro os sujeitados e oprimidos, ao invés dos nobres; o tédio se combate com a "casuística do pecado, autocrítica, inquisição da consciência", o que não parece trazer jovialidade ou sossego para a consciência. Há também no cristianismo o cultivo de um afeto intenso para com a divindade manifesto na oração e "nele o mais elevado é visto como inatingível, como dádiva, como 'graça'. Nele falta também o espaço público; o esconderijo, o aposento escuro é cristão"14. A higiene é vista como sensualidade, e ressentimento e sentimento de vingança são cultivados com intensidade, o que fica evidenciado pelas perseguições aos que se comportam de modo diverso do padrão determinado pela comunidade.

Concluindo esta pequena análise do Anticristo temos também que o budismo é para Nietzsche uma religião de homens tardios, raças bondosas e super-espirituais, típico fenômeno do ocaso de uma civilização. O cristianismo, por seu turno tende a ser atrativo para bárbaros com sede de domínio, ação e conquista, uma vez que os sempre oprimidos não vão querer o fim dos desejos, antes, vão querer a realização de sonhos longamente nutridos, a vingança entre eles.

Essas palavras elogiosas parecem sugerir uma postura geral positiva na leitura de Nietzsche acerca do budismo. Cabe mencionar aqui que logo no início do parágrafo 20 ele afirma serem ambas religiões niilistas e decadentes. Isso nos convida a por esses elogios em perspectiva. Passemos em revista agora passagens da Genealogia da Moral.

A terceira dissertação da Genealogia apresenta uma análise do que Nietzsche chama de ideais ascéticos. Grosso modo podemos dizer que ideal ascético é todo tipo de ideal que se coloca em oposição à vida, localizando o sentido ou a felicidade em algo diverso dela, seja arte, ciência ou

\footnotetext{
${ }^{14}$ Friedrich Nietzsche, Anticristo e Ditirambos a Dionisio, 26.
} 
religião. Apresentarei algo da dimensão religiosa com objetivo de mostrar que as tradições indianas são criticadas por Nietzsche como partícipes desse ideal.

Quando falamos de religião, a figura que emerge é a do sacerdote ascético. A característica fundamental do sacerdote ascético é tratar a vida negativamente, como se ela fosse fundamentalmente errada, "como um erro que se refuta" dirá Nietzsche e tal refutação se dá pela ação. Como o asceta age de modo a negar a vida? Entre outras coisas mediante as práticas de mortificação como jejum, abstinência sexual entre outras. Daí resulta o ressentimento diante daqueles que não se entregam a tais práticas, o ar de superioridade assumido por todos os sacerdotes desde sempre frente àqueles que não são fortes o bastante para renunciar à vida. $\mathrm{O}$ sacerdote ascético é o padre, o brâmane e o monge budista. Isso mostra uma grande diferença em relação aos elogios expostos no Anticristo. Senão vejamos.

No parágrafo 17, ao falar sobre o sacerdote ascético como médico que não cura e na verdade fabrica a doença para combater-lhe os sintomas, temos algumas importantes referências ao oriente e também ao cristianismo. Como o cristianismo é sempre o alvo religioso preferencial de Nietzsche, mencionaremos especificamente as referências orientais. A primeira observação diz respeito a noção de redenção, o estado supremo. As características de tal estado são "hipnotização e quietude total (...) desprendimento de toda ilusão, sendo 'saber', 'verdade', 'ser', sendo libertação de todo fim, todo ato, todo desejo, sendo estar além também do bem e do mal.” Entendemos que tais características se aplicam também aos modos orientais de pensar a libertação. Especialmente palavras como quietude, libertar-se da ilusão e do desejo fazem pensar imediatamente na tradição dos Upanishades e no budismo.

No pensamento indiano é bastante difundida a ideia de um tipo de entidade (na falta de palavra melhor) por trás dos fenômenos, tal entidade chama-se atman e seria o real em contraposição ao que careceria de realidade, o campo fenomênico. A libertação consiste em entrar em contato com o atman mediante práticas espirituais. Alcançar tal objetivo é sair da ilusão para a verdade. A tradição budista mantém a mesma ideia fundamental, qual seja, um conjunto de práticas pode nos conduzir a ver as coisas como elas realmente são, ao fim do sofrimento, que não seria o contato com o Eu superior ou atman, mas passaria pela realização do não-eu ou anatma, anatta, em páli. Por fim tal libertação implica superar a moralidade, ficar além do bem e do mal. De acordo com Nietzsche tal ideia é comum ao cristianismo bem como ao budismo e ao hinduísmo, seria um corolário da transcendência implicada na ideia de libertação.

Honremos, pois, a 'redenção', como aparece nas grandes religiões; em compensação, para nós é um pouco difícil permanecer sérios ante a estima em que o sono profundo é tido por esses cansados da vida, demasiado cansados até mesmo para sonhar - sono profundo entendido como ingresso no Brahma, como efetivação da unio mystica com Deus. ${ }^{15}$

Por fim, no parágrafo 7 desta terceira dissertação temos uma referência que sugere ter lido Nietzsche algo de literatura budista, além de aproximar budismo e cristianismo em termos de desconfiança diante da sexualidade. Diz-nos Nietzsche: "Qualquer filósofo falaria como Buda certa vez, ao lhe anunciarem o nascimento de um filho: 'Nasceu-me Râhula, um grilhão foi forjado para mim"'. Na sequência temos uma passagem repetida à exaustão no cânone páli:

[...] para todo 'espírito livre' deveria chegar uma hora de reflexão, supondo que tivesse tido antes uma hora irrefletida, como uma vez ocorreu ao

${ }^{15}$ Friedrich Nietzsche, Genealogia da Moral, trad., ed. Paulo César de Souza (São Paulo: Companhia das letras, 2009), 114. 
próprio Buda - 'estreita e opressiva', pensou consigo, 'é a vida no lar, local de impureza; a liberdade consiste em abandonar o lar'. ${ }^{16}$

O contexto onde aparece essa referência é uma discussão acerca da irritação dos filósofos quanto a sexualidade e a aceitação da parte destes do ideal ascético. A independência aparece vinculada ao abandono da servidão da família e da vida mundana. Isto quer dizer que o budismo para Nietzsche se enquadra no espectro de defensores do ideal ascético, com toda carga negativa que isso implica do ponto de vista do filósofo.

Concluímos de tais passagens que temos elementos para questionar essa suposta avaliação positiva de Nietzsche quanto ao budismo, apesar de certa dose de elogio e talvez de admiração. Em segundo lugar citações de passagens canônicas sugerem alguma familiaridade com textos budistas ou com estudos acerca do budismo em circulação durante sua vida, conforme bem aponta Mistry ao falar acerca das fontes orientalistas disponíveis na biblioteca pessoal do autor e obras que ele pegou emprestado na universidade de Basiléia.

No primeiro grupo - selecionando os que falam especificamente de budismo - temos os Ensaios vol. II de Max Müller, Buddha: sua vida, sua obra, sua ordem, de Hermann Oldenberg. No segundo grupo temos $A$ religião do Buddha de Carl Friedrich Koeppen em dois volumes e no Nachlass há menções a um livro de Henrik Kern, provavelmente O Budismo e sua História na Índia de 1884. Além disso ele teve contato com pelo menos um texto do cânone páli, a saber, uma tradução inglesa do sutta-nipata, conforme menciona em carta a Gersdorff.

Honestamente, eu admiro o belo instinto de sua amizade - espero que a expressão não soe bestial para você - de que agora você deve se haver com estes ditos Indianos, ao passo que eu, dois meses atrás voltava minha atenção para a Índia com um tipo de sede crescente. Peguei emprestado do Sr. Widemann, amigo de Schmeitzner, a tradução inglesa do Sutta Nipata, algo das escrituras budistas, e já fiz uso doméstico de um dos refrões do sutta: 'Assim eu ando, solitário como um rinoceronte'. A representação da indignidade da vida e do engano/ilusão de todas as metas, frequentemente causou forte impressão em mim, particularmente quando estou acamado e doente, de modo que há muito desejo ouvir algo mais acerca disso sem, é claro, as adulterações dos idiomas judaico-cristãos. ${ }^{17}$

A questão que se coloca então é a seguinte: como entender o diagnóstico de Nietzsche acerca do budismo - religião niilista e decadente - a partir das fontes lidas por este autor? As fontes consultadas por ele apresentam também conclusão semelhante? Lembremos que Schopenhauer já havia apontado a semelhança entre o nada como resultando da negação da vontade com o Nirvana dos budistas. Não nos parece correto neste tipo de leitura supor uma incompreensão, posto que estamos diante de um acesso restrito a fontes primárias e também estamos diante de um filósofo preocupado com a elaboração de sua filosofia e não com o budismo. Neste sentido, podemos nos perguntar acerca do modo como Nietzsche se apropria de ideias e conceitos budistas no contexto de sua filosofia e acerca de eventuais influências do budismo na elaboração de temas dessa mesma filosofia. Só depois de responder tais questões poderemos estabelecer comparações mais amplas com o budismo theravada e mesmo com outras escolas budistas e a filosofia de Nietzsche.

${ }^{16}$ Friedrich Nietzsche, Genealogia da Moral, 89.

${ }^{17}$ Freny Mistry, Nietzsche and Buddhism: Prolegomenon to a Comparative Study (Berlin, New York: W. de Gruyter, 1981$), 17$. 
Apresentarei neste passo uma breve análise da bibliografia lida até o presente momento. Destacarei os seguintes trabalhos: Nietzsche and Buddhism: Prolegomenon to a Comparative Study de Freny Mistry; Nietzsche and Buddhism: a Study in Nibilism and Ironic Affinities de Robert G. Morrison. Alguns artigos, entre eles: Nietzsche's Early Enconunters with Asian Thought de Johan Figl; Nietzsche and the suffering of the indian ascetic de Michel Hulin e Nietasches Trans-European Eye de Merryn Sprung, todos estes compõem a coletânea organizada por Graham Parkes intitulada Nietzsche and Asian Thought. Naturalmente não farei uma análise exaustiva neste momento, pretendo apenas mapear algumas tendências quanto ao estudo do tema Nietzsche e o Budismo.

A tese fundamental de Freny Mistry é enunciada logo na introdução de sua obra: um estudo cuidadoso revela entre Nietzsche e o budismo mais semelhanças do que diferenças. Ela se opõe, portanto ao texto de Bertrand Russell segundo o qual há um antagonismo entre esses pensamentos, embora note a crítica de Nietzsche à "compaixão universal" ela nota que na ética do filósofo não há um desprezo por esta forma de simpatia. Enfim, segundo ela o objetivo do livro é mostrar que tanto o budismo quanto Nietzsche apresentam caminhos semelhantes de autorredenção; o Além-do-Homem seria algo budista em sua essência, conforme citação do dhammapada em seu capítulo VIII, verso 103 que diz: "Embora um homem conquiste numa batalha mil vezes mil homens, o maior vitorioso em batalha seria em verdade aquele que conquistasse a si mesmo."18 Este último ponto me faz lembrar da tese de Müller-Lauter segundo a qual há em Nietzsche duas formas de conceber o Além-do-Homem, uma como sábio e outra como guerreiro e não um guerreiro interiorizado, um conquistador de fato. A conquista de si mesmo seria pensada do mesmo modo nos dois casos? Parece não ser possível pensar um Alémdo-Homem como guerreiro interiorizado a partir dessa citação. ${ }^{19}$

Segundo Mistry, a metodologia é investigar divergências e afinidades nas filosofias de Nietzsche e Buddha a partir de uma perspectiva temática. Ela aponta o caráter ambíguo das afirmações de Nietzsche sobre o budismo como típico da realidade do século XIX em termos de fontes e interpretações motivadas por interesses específicos da época. Apesar de tudo isso - e estranhamente, eu diria - vários tópicos da filosofia de Nietzsche são semelhantes ou permutáveis pelos equivalentes budistas.

O eterno retorno, segundo a autora, embora seja visto pelo próprio Nietzsche como contrário ao nirvana, pode ser aproximado do budismo na medida em que defende a persistência criativa e a contínua superação nesta realidade. Me parece problemático isso posto que não há fim do ciclo de repetições para Nietzsche, ao passo que para o budismo o ciclo cessa com o nirvana.

Da parte de Freny Mistry notamos uma ênfase grande na busca e defesa de semelhanças entre Nietzsche e o budismo e uma minimização das diferenças entre esses dois pensamentos pois as semelhanças são pensadas como mais importantes e significativas.

O livro de Morrison, ${ }^{20}$ por sua vez, difere do citado anteriormente não só quanto ao subtítulo, mas também quanto a abordagem defendida pelo autor. Ele pretende na primeira parte do livro explicar a leitura e os equívocos de Nietzsche quanto ao modo com este leu o budismo, a saber, como essencialmente niilista. Isto ocupa os três primeiros capítulos da obra. Ao longo da segunda e maior parte do livro, o autor traça o que ele chama de "afinidades irônicas" entre os sistemas de Nietzsche e do Buddha. Neste sentido me parece haver um retorno a abordagem defendida por Mistry, qual seja, minimizar as diferenças e enfatizar as semelhanças entre os dois pensamentos.

\footnotetext{
${ }^{18}$ Usamos aqui a tradução direto do páli para o português feita por Nissim Cohen, publicada pela editora Palas Athena.

19 Ressaltemos aqui que o tema da conquista de si mesmo como conquista interior não é exclusivo do budismo, encontramos esta ideia em Platão também, bem como em outras tradições de sabedoria da humanidade.

${ }^{20}$ Robert G Morrison, Nietzsche and Buddhism: a Study in Nibilism and Ironic Affinities (New York: OUP, 1997).
} 
O livro apresenta comparações muito interessantes sobre os agregados e as pequenas coisas e sobre auto-superação de cultivo da mente ou citta-bhavana, mas na medida em que há uma incompreensão quanto ao fim último do caminho budista e quanto a natureza não-niilista do budismo, entendo necessário investigar se as leituras feitas por Nietzsche tiveram impacto em suas formulações acerca do budismo e em que medida podemos falar de leituras sistemáticas feitas por ele quanto ao assunto do budismo. Além disso, é importante mencionar que as afinidades irônicas não parecem se dar com relação aos aspectos mais importantes do ensinamento budista e que apesar dessas afinidades as diferenças em termos de objetivos e mesmo visão de mundo como base para tais crenças.

Gostaria de passar agora aos artigos da coletânea organizada por Graham Parkes ${ }^{21}$ citados acima, com o objetivo de questionar a extensão do conhecimento de Nietzsche acerca do budismo ou mesmo de seu interesse com relação a esse assunto.

O artigo de Figl nos apresenta um estudo de anotações da juventude de Nietzsche que ainda não foram publicadas. Essas notas sugerem já haver uma certa aproximação e interesse de nosso autor desde os tempos de escola pelo pensamento indiano em geral e budista em particular, o que fortalece a ideia de um interesse mais forte da parte de Nietzsche por esses assuntos desde cedo em sua vida.

Michel Hulin pretende analisar como Nietzsche lida com o ascetismo indiano ao longo de sua carreira filosófica. Ele passa a primeira metade do artigo analisando o conjunto de ideias que Nietzsche chamava comumente de brahmanismo. A conclusão a que ele chega é a seguinte:

Coletivamente os brâmanes encarnam, da melhor maneira, uma das figuras favoritas da imaginação nietzschiana: membros de pequenos grupos de elitistas, aristocratas, unidos por uma disciplina de ferro aceita livremente, perto dos centros de poder, mas que se retiram a partir da fase em que a grandes figuras do mundo desempenhem os seus papéis, e inteiramente dedicados a uma tarefa histórica que transcende os indivíduos gerações. ${ }^{22}$

Há certa admiração em Nietzsche pelos brâmanes como grupo de elite que vence a si mesmo e consegue exercer poder produzindo um sentido para toda uma comunidade.

Quando nos voltamos para o budismo a situação é de complexidade e paradoxo, diz-nos Hulin. O primeiro ponto observado é que Nietzsche vê o budismo como "uma seita elitista que em certa altura afastou-se do brahmanismo". Com isso se diminui o papel das crenças populares e o papel expansionista ou missionário do budismo. Diferentemente do cristianismo tal reação não surgiria do populacho, mas sim de um tipo de "exaustão fisiológica" das elites. Neste cenário, Hulin aponta para um aspecto fundamental que aparece no Anticristo, qual seja, a questão do ascetismo.

Nietzsche diminui o papel do ascetismo na medida em que o caracteriza no campo do budismo como higiene. Nesse sentido há uma suavização das práticas budistas na obra do filósofo. Ele não menciona que os ensinamentos budistas se dirigem principalmente para monges, que esses monges esmolam o alimento e que a disciplina monástica envolve um grande número de regras ascéticas. Tudo isso está claramente apresentado no livro de Oldenberg que se encontra entre os livros da biblioteca de Nietzsche.

\footnotetext{
${ }^{21}$ Graham Parkes (org.) Nietzsche and Asian thought (Chicago: The Universitiy of Chicago Press, 1996).

${ }^{22}$ Graham Parkes (org.) Nietzsche and Asian thought, 70.
} 
Nietzsche parece construir um budismo que não corresponde aos dados disponíveis ao que ele teria lido. Ele pretende elaborar "fantasma poético que flutua entre os dois tipos de regras", a saber, as regras monásticas e aquelas destinadas aos leigos. De acordo com Hulin a agenda de Nietzsche que o leva a suavizar e descaracterizar desta forma o budismo é usá-lo em sua crítica ao cristianismo.

Por fim gostaria de falar sobre os problemas levantados por Mervin Sprung. Seu artigo defende fundamentalmente a tese segundo a qual Nietzsche não se interessou tanto assim pelo pensamento do oriente e aponta como evidência disso as poucas passagens que discutem temas orientais no material publicado, a reduzida presença de discussões ou manifestação de interesse de Nietzsche pelo assunto nas cartas escritas pelo filósofo ao longo de sua vida. A partir desse diagnóstico o autor sugere como investigação possível considerarmos até que ponto é possível que alguns temas da filosofia de Nietzsche tenham origem em sua leitura acerca de ideias orientais.

Especificamente acerca do budismo a leitura de Sprung é de que Nietzsche não se afasta muito do diagnóstico proposto por Schopenhauer, de modo que ele

não exibe consciência acerca da filosofia budista além da doutrina da libertação do sofrimento apesar dele demonstrar perspicácia ao sentir a liberdade do autoengano moral nas palavras do Buddha e isto sugere alguma leitura dos discursos originais, embora não tenhamos pistas acerca de quais seriam tais discursos. Ele cita o dhammapada e possivelmente não conhecia nada mais. ${ }^{23}$

O que nós temos até o presente? Leituras que tendem a minimizar as diferenças apresentando uma semelhança que força até o limite as duas visões filosóficas, como é o caso do trabalho de Mistry. Temos a leitura mais interessante de Morrison, que entendemos apresentar semelhanças bastante profícuas, mas que por outro lado me leva a perguntar: como propostas de modos de vida tão distintos como as apresentadas por Nietzsche ou pelo budismo podem ser tão aparentadas, ainda que sob a rubrica de afinidades irônicas? Nesse sentido entendemos ser fundamental não apenas notar as limitações de material que implicaram em uma leitura incompleta, mas também é preciso passar em revista os grandes temas do budismo em comparação com o pensamento de um Nietzsche leitor não só do budismo, mas do pensamento oriental de modo geral, tomando como referência o material que ele teria lido, conforme levantamento citado acima.

Os artigos citados levantam problemas interessantes e fornecem material que podem orientar essa investigação, na medida em que apresentam problemas quanto às fontes e a extensão dos interesses de Nietzsche. Tais investigações ajudam a problematizar tanto a leitura de Mistry quanto a de Morrison, bem como demandam que se faça uma investigação detalhada acerca desses assuntos.

Temos então em Nietzsche, de acordo com a carta citada acima, uma sede crescente pelos ditos do budismo. Tal sede o leva a buscar os melhores trabalhos disponíveis em sua época sobre o tema e mesmo fontes primárias direto do cânone páli. Fica claro, portanto, que há, também neste autor, um diálogo entre filosofia e oriente.

Embora a questão do budismo não seja central ao pensamento de Nietzsche, entendemos que tal tema possui relevância quando o situamos no contexto da filosofia da religião nietzschiana em pelo menos dois aspectos. Em primeiro lugar, é inegável que o tema religião é caro a

${ }^{23}$ Graham Parkes (org.) Nietzsche and Asian thought, 82. 
Nietzsche, notadamente sua crítica do cristianismo e sua defesa de um certo tipo de paganismo representado pela figura de Dionísio. São inúmeras as passagens de suas obras que lidam com esses assuntos a partir de chaves interpretativas que sugerem a possibilidade de um tipo de teoria geral das religiões a partir de suas obras. Nesse sentido cabe investigar o impacto que esse interesse pelo budismo teve em sua obra. Em segundo lugar, podemos tomar o caso "Nietzsche e o budismo" como modelo para analisar o fenômeno "contatos entre pensamento oriental e filosofia". Considerando essas reflexões, a pergunta que devemos buscar responder agora é a pergunta sobre o método: como empreender este estudo?

Identificamos três abordagens possíveis quanto ao estudo. A primeira abordagem parte exclusivamente das fontes materiais as quais Nietzsche teve acesso. Nesse contexto, o budismo estudado pelo filósofo é aquele da tradição theravada, cujas escrituras constituem o cânone páli. Nesse sentido os livros homônimos de Freny Mistry e Robert G. Morrisson, Nietz̧sche and Buddhism, são os melhores exemplos disponíveis, além da coletânea Nietz̧sche and Asian thought, organizada por Graham Parkes, todos mencionados acima.

O segundo modo de lidar com essa questão é ampliar o foco da comparação, de modo a incluir não apenas o budismo theravada, mas qualquer tradição budista. Claro está que o foco desse tipo de estudo é comparativo, não se trata de reconstruir a compreensão do autor acerca do assunto, mas sim comparar tópicos de sua filosofia com aspectos desta ou daquela tradição. Como exemplos podemos citar o livro Nietzsche and Buddhist Philosophy de Antoine Panaïoti, e livros como Nietzsche and Zen: Self Overcoming Without a Self de André van der Braak e Buddha Is Dead: Nietzsche and the Dawn of European Zen, de Manu Bazzano.

Uma terceira forma de abordar esse assunto diz respeito às relações entre a filosofia de Nietzsche e a filosofia japonesa. O ponto especifico desta abordagem é que neste caso não se trata do oriente chegando ao ocidente, mas o contrário. Nietzsche foi lido no Japão e influenciou toda uma geração de filósofos. Trata-se, pois, de problema diverso daquele tratado aqui, não se trata das relações entre Nietzsche e o budismo, mas sim das relações entre a filosofia de Nietzsche e a filosofia japonesa. Portanto, excluímos esta terceira abordagem de nossa comparação.

Considerando as duas primeiras abordagens mencionadas, escolhemos a primeira, apesar de estudos extensos sobre o assunto conforme citamos acima. Tal se deve ao fato de que discordamos de pontos importantes das pesquisas tanto de Mistry quanto de Morrison. De modo geral, o grande problema dessas leituras é o esforço na busca de afinidades entre o budismo e o pensamento de Nietzsche. Mistry é explícita quanto a isso já na introdução, conforme mencionamos e pretende que seu trabalho seja um prolegômeno para um estudo comparativo. Morrison, por sua vez, apresenta o que entendemos ser uma versão mitigada dessa busca por semelhanças já exposta no subtítulo da obra um estudo sobre nïlismo e afinidades irônicas. A estratégia de ambos os estudos se efetiva na escolha de temas comuns e comparando os mesmos entre os dois modos de pensamento envolvidos. O modelo é: Nietzsche diz isso assim, o budismo diz deste outro modo e há uma semelhança entre ambos.

Entendemos que há um critério metodológico fundamental a ser observado no estudo das relações entre o budismo e a obra de Nietzsche, que consiste em investigar se a semelhança entre ideias se dá quanto a origem e resultados das mesmas. Entendemos que os comentadores tendem a tomar semelhanças de formulação sem levar em consideração o que fundamenta determinado conceito tanto na doutrina budista quanto na filosofia de Nietzsche. A título de exemplo podemos apresentar a questão da não substancialidade do eu tanto no budismo como em Nietzsche. O filósofo alemão chega a tal conclusão tomando como base descobertas da biologia no que tange ao estudo das células ao passo que a doutrina budista de anatta, não-eu ou não alma deriva da experiência da iluminação do próprio Buda ao invés de ser resultado de evidências científicas. 
Temos, portanto, que desde sua origem a filosofia dialoga com a religião, seja polemizando com esta, seja concordando e dando a ela suporte teórico. Com o cristianismo temos uma longa tradição de submissão da filosofia à apologética cristã, fenômeno que começa a mudar com o renascimento. Apesar disso é importante notar que a filosofia sempre está numa posição a partir do cristianismo, concordando ou discordando dele. A partir do movimento conhecido como orientalismo temos a possibilidade de conhecer tradições religiosas sofisticadas e sem ligação nenhuma com o monoteísmo, seja ele cristão, judaico ou islâmico. Nesse sentido o diálogo entre filosofia e religião se enriquece, posto que é possível aos filósofos conhecer livros sagrados como os da tradição budista. Tal é o caso de autores como Schopenhauer e Nietzsche.

Em Schopenhauer temos um contato com o budismo posterior ao contato do autor com o pensamento dos Upanishades, de modo que ele faz uma aproximação entre as tradições ignorando as grandes diferenças entre ambas e buscando nelas exemplos confirmatórios de sua visão de mundo. Em Nietzsche temos críticas e elogios ao budismo, embora tenhamos apontado que os elogios se situam num contexto maior de crítica, na medida em que budismo também é uma religião niilista junto com o cristianismo. Somemos a isso a sede pelos ditos do budismo mencionada pelo autor em carta e temos uma investigação promissora diante de nós. Além disso, é importante notar que esta conclusão abre caminho para que possamos criticar importantes estudos acerca das relações entre Nietzsche e o budismo. Gostaríamos de ressaltar que este texto tem como objetivo tão somente apontar caminhos possíveis, a análise efetiva do tema não caberia em apenas um artigo. 